\title{
Impacts of groundwater extraction on salinization risk in a semi-arid floodplain
}

\author{
S. Alaghmand ${ }^{1}$, S. Beecham ${ }^{1}$, and A. Hassanli ${ }^{1,2}$ \\ ${ }^{1}$ Centre for Water Management and Reuse, School of Natural and Built Environments, University of South Australia, \\ Adelaide, Australia \\ ${ }^{2}$ College of Agriculture, Shiraz University, Shiraz, Iran
}

Correspondence to: S. Alaghmand (sina.alaghmand@mymail.unisa.edu.au)

Received: 24 April 2013 - Published in Nat. Hazards Earth Syst. Sci. Discuss.: 26 July 2013

Revised: 29 October 2013 - Accepted: 6 November 2013 - Published: 23 December 2013

\begin{abstract}
In the lower River Murray in Australia, a combination of a reduction in the frequency, duration and magnitude of natural floods, rising saline water tables in floodplains, and excessive evapotranspiration have led to an irrigationinduced groundwater mound forcing the naturally saline groundwater onto the floodplain. It is during the attenuation phase of floods that these large salt accumulations are likely to be mobilised and discharged into the river. This has been highlighted as the most significant risk in the MurrayDarling Basin and the South Australian Government and catchment management authorities have subsequently developed salt interception schemes (SIS). The aim of these schemes is to reduce the hydraulic gradient that drives the regional saline groundwater towards the River Murray. This paper investigates the interactions between a river (River Murray in South Australia) and a saline semi-arid floodplain (Clark's floodplain) that is significantly influenced by groundwater lowering due to a particular SIS. The results confirm that groundwater extraction maintains a lower water table and a higher amount of fresh river water flux to the saline floodplain aquifer. In terms of salinity, this may lead to less solute stored in the floodplain aquifer. This occurs through three mechanisms, namely extraction of the solute mass from the system, reducing the saline groundwater flux from the highland to the floodplain and changing the floodplain groundwater regime from a losing to a gaining one. It is shown that groundwater extraction is able to remove some of the solute stored in the unsaturated zone and this can mitigate the floodplain salinity risk. A conceptual model of the impact of groundwater extraction on floodplain salinization has been developed.
\end{abstract}

\section{Introduction}

As groundwater moves from a highland aquifer to the river, it needs to pass under the floodplain. Due to the high rate of evapotranspiration in arid and semi-arid regions such as the lower River Murray in South Australia, part of the groundwater discharges to the floodplain and leaves salt in the floodplain soil (Fig. 1). Overbank floods leach salt from the upper soil layers to the groundwater, wash salt off the soil profile and add fresh water to the floodplain soils. The highly variable nature of surface flow in arid/semi-arid regions has led to regulation of rivers by weirs and storage infrastructure (Jolly et al., 1996). This has affected surface-groundwater interactions in the floodplains. For example, the removal of salt by overbank floods occurs less frequently. A combination of reduction in the frequency, duration and magnitude of natural floods, rising saline water tables in floodplains (due to river manipulations and irrigated agricultural land drainage) and excessive evapotranspiration (ET) have led to an irrigation-induced groundwater mound forcing the naturally saline groundwater onto the floodplain at a relatively high flow rate (Jolly et al., 1993; Holland et al., 2009a). This has caused a reduction of leaching of salt from root zones and the accumulation of salt in unsaturated zones, causing dieback of environmentally important riparian vegetation such as red gum (Eucalyptus camaldulensis) and black box (Eucalytpuslargiflorens) and a decline in river water quality (Allison, 1990; Herczeg, 1993; Jolly et al., 1996; Peck, 1973, 2003; Jolly et al., 1993). Another example is the Mona Park district along the Burdekin River in northern Australia, where widespread use and application of "imported" surface 


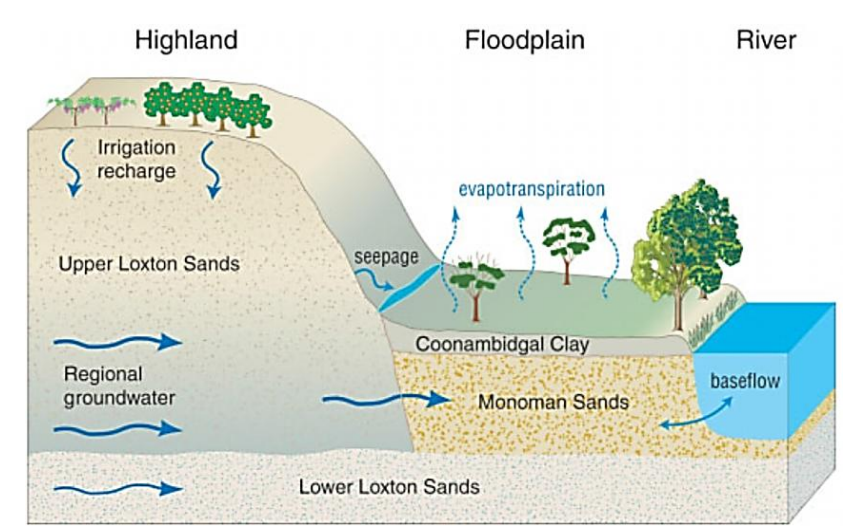

Fig. 1. Conceptual model of groundwater inputs to the floodplain and potential groundwater discharge pathways within the floodplain in the lower River Murray (Holland et al., 2009a).

water resulted in rising water table levels and the formation of a large groundwater mound during the wet season of 2000 (Petheram et al., 2008).

Prior to 2010, a high river flood event had not occurred for $13 \mathrm{yr}$. However, salt accumulation had continued over this period. The Independent Audit Group for Salinity (IAGSalinity) mentioned the likelihood of severe salt accessions during flood recessions in their report (MDBA, 2010). This was articulated in their 1st recommendation and in the previous audit reports. IAG-Salinity considers this the most significant risk in the Murray-Darling Basin. As an effort to reduce the immediate risk of river salt accession induced by increased saline groundwater levels, due to field irrigation and excessive evaporation, the South Australian Government and catchment management authorities have developed salt interception schemes to pump the highly saline groundwater mixed with irrigation recharge from the floodplain to evaporation basins (DWR, 2001). Each bore yields $2-3 \mathrm{~L} \mathrm{~s}^{-1}$ to reduce the hydraulic gradient that drives the regional saline groundwater towards the River Murray and this has improved river water quality (Berens et al., 2009). The SIS bores have been in operation since August 2005 except for some periods of shut down (e.g. from November 2006 to May 2007). It is expected they will prevent about 200 tonnes of salt per day from entering the River Murray by 2040 (White et al., 2009). Before the SISs were operational, an irrigation-induced groundwater mound forcing the naturally saline groundwater onto the floodplain at a relatively high flow rate, thereby increasing soil salinity in the root zone of the floodplain woodlands (Viezzoli et al., 2009; Doble, 2004) (Fig. 1). For instance at Clark's floodplain, field investigations have shown that significant salt accumulation and vegetation dieback has occurred. This is due to evapotranspiration from rising floodplain water tables, altered flow regimes and increased irrigation in the surrounding highlands on this floodplain (Doble, 2004).
Some of the most challenging aspects of water resources studies concern the interaction between surface and groundwater (Wheater et al., 2010). Rassam (2011) classified flow and solute exchange between a river and a floodplain aquifer into four categories: (1) natural exchange flux due to river stage fluctuations such as flooding (within-bank or overbank), base-flow discharge, reservoir regulations, etc. (Squillace, 1996; Chen, 2003; Moench and Barlow, 2000; Brutsaert and Lopez, 1998); (2) exchange flux induced by pumping wells in adjacent aquifers (Chen and Shu, 2006; Sophocleous et al., 1995; Sun and Zhan, 2007); (3) exchange flux due to changes in recharge rates; and (4) exchange flux due to changes in evapotranspiration. Groundwater extraction is an important process that affects the exchange flux between surface water and groundwater. Extraction-induced river depletion is defined as the reduction of river flow due to induced infiltration of stream water into the aquifer or the capture of aquifer discharge to the river (Rassam, 2011). The temporal and spatial scales at which these processes contribute to the exchange flux is variable. For instance, river depletion resulting from groundwater extraction is delayed by time lags that range from days to hundreds of years. Likewise, the extent of the groundwater extraction activity may vary along a river reach, thus leading to gaining and losing sub-reaches. Because of the intensive spatial and temporal variability there is a need for dynamic modelling of their impacts on river flows.

Near-river aquifer systems are complex due to the difficulties associated with estimating flows and solute mass transfers into and out of the aquifer, the complicated nature of the groundwater-surface water interaction processes, and the uncertainty of aquifer properties (Sophocleous, 2010). Because of this complexity, computer models are often used to model groundwater systems and to estimate the exchange flux between surface water and groundwater. These models are computer-based numerical solutions to the boundary value problems of concern (Wheater et al., 2010). In this regard, the need to accurately quantify and forecast surface and groundwater interactions has promoted the use of physically based numerical modelling approaches in many studies (Loague and VanderKwaak, 2004; Ebel and Loague, 2006; Beven and Binley, 1992; Beven, 2006, 2002, 2001; Nasonova and Gusev, 2008). Physically based models are generally founded on the blueprint for a physically based mathematical model of a complete hydrological system developed by Freeze and Harlan (1969). Popular physically based models include HydroGeoSphere (HGS) (Therrien et al., 2005), Integrated Hydrology Model (InHM) (VanderKwaak and Loague, 2001; VanderKwaak, 1999), MODular Hydrologic Modelling System (MODHMS) (HydroGeoLogic Inc, 2006), ParFlow (Kollet and Maxwell, 2006), MIKE SHE (Abbott et al., 1986), Modular Modelling System (MMS) (Leavesley et al., 1996), CATchmentHYdrology (CATHY) (Camporese et al., 2010), FIPR hydrologic model (FHM) (Ross et al., 1997), and Penn State Integrated Hydrologic Model (PIHM) (Qu and Duffy, 


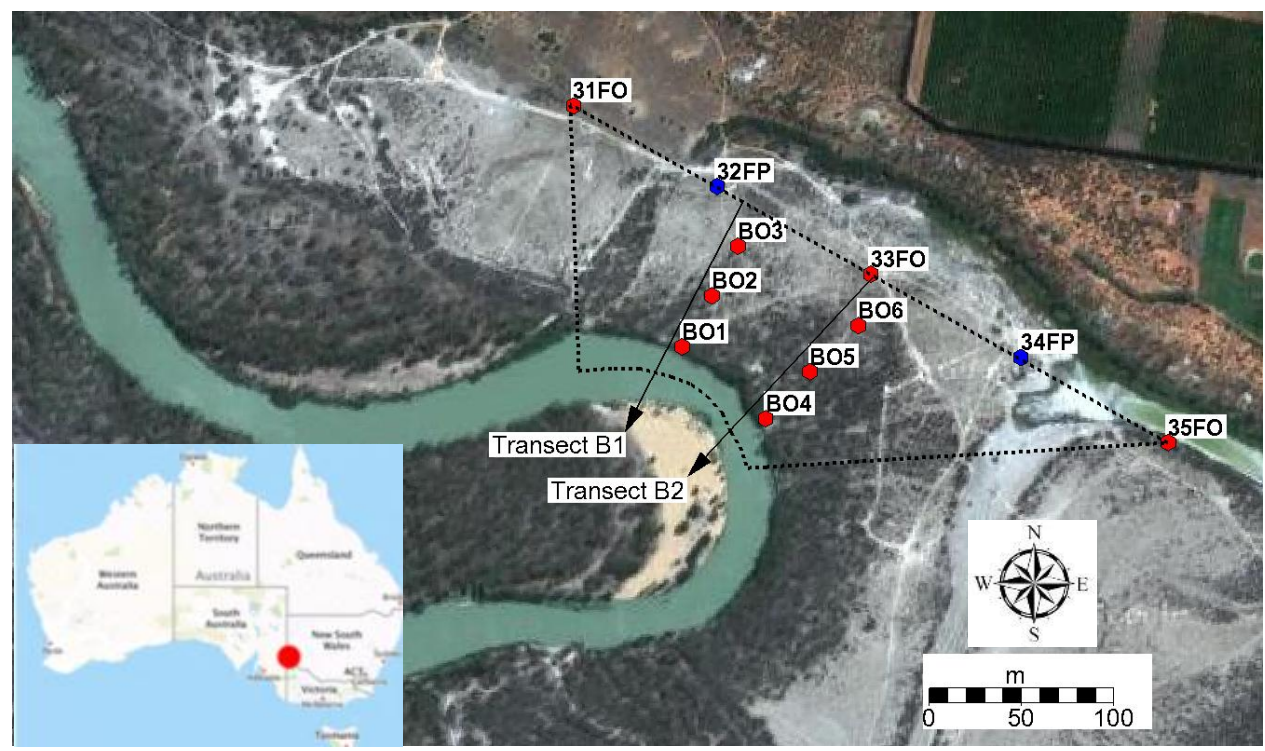

Fig. 2. Configuration of SIS production wells (in blue) and observation wells (in red) at Clark's floodplain. The inset map shows the location of the Bookpurnong floodplain in Australia.

2007). Modelling of surface-groundwater interactions needs knowledge of groundwater modelling, but also a detailed understanding of the exchange processes that occur between the surface and sub-surface domains (Barnett et al., 2012). Surface-groundwater interactions have been investigated in several studies (Hoehn and Scholtis, 2011; Lenahan and Bristow, 2010; Sophocleous and Perkins, 2000; Winter, 1999; Kollet and Maxwell, 2006; Krause et al., 2007; Lamontagne et al., 2005; Liang et al., 2007; Meire et al., 2010; Panday and Huyakorn, 2004; Shlychkov, 2008), but floodplains in arid/semi-arid regions have received considerably less attention (Jolly et al., 2008). One of the major limitations in this regard is lack of high quality observed data (Pilgrim et al., 1988). This has resulted in application of experiences from humid regions to drier regions without knowledge of the consequences. At best, such results will be highly inaccurate while at worst, they can be adopted for inappropriate management solutions which disregards the key features of arid/semi-arid areas (Wheater et al., 2010). One issue can be the key role of salinity in arid and semi-arid floodplains (Hart et al., 1991) and the role of the unsaturated zone as one of the main components of solute mass storage in the system.

This paper investigates the interactions between a river (River Murray in South Australia) and a saline floodplain (Clark's floodplain) in a semi-arid area significantly influenced by groundwater lowering due to the Bookpurnong SIS. Hence, the main objective of this research is to quantify the relative impacts of the groundwater lowering on the surfacegroundwater interactions in a semi-arid saline floodplain to investigate the dynamics of both flow and solute. To this aim two numerical model scenarios are defined, including one with SIS operation (with-SIS) and another without SIS operation (without-SIS). The question is what could be the water and solute dynamic at the study site if there was not any groundwater lowering. It was hypothesized that groundwater extraction via the SIS may lead to a lower water table and a less saline floodplain aquifer. Moreover, the numerical model's capabilities to reproduce surface and groundwater flow and solute dynamics are also tested. In this regard, a physically based numerical model is developed and calibrated according to well-documented observed surface and groundwater data. This paper describes the development and calibration of a numerical model and the application of this model according to the defined scenarios. During evaluation of the scenarios, the calibrated model (2006-2010) is used without further parameter changes.

\section{Study site}

The study was Clark's floodplain adjacent to the River Murray in the Bookpurnong Irrigation District of the Riverland region of South Australia (Fig. 2). The area, which is located approximately $12 \mathrm{~km}$ upstream from the township of Loxton, has been the focus of trials to manage a marked decline in tree health that has been observed along the River Murray in South Australia. The study site is typically vegetated by a mixture of river red gum (Eucalyptus camaldulensis), black box (Eucalyptus largiflorens), river cooba (Acacia stenophylla) and lignum (Muehlenbeckia florenta). The study site is located within the semi-arid inland of Australia, with annual rainfall varying between 200 and $300 \mathrm{~mm}$ and annual potential evaporation of approximately $1800 \mathrm{~mm}$. 


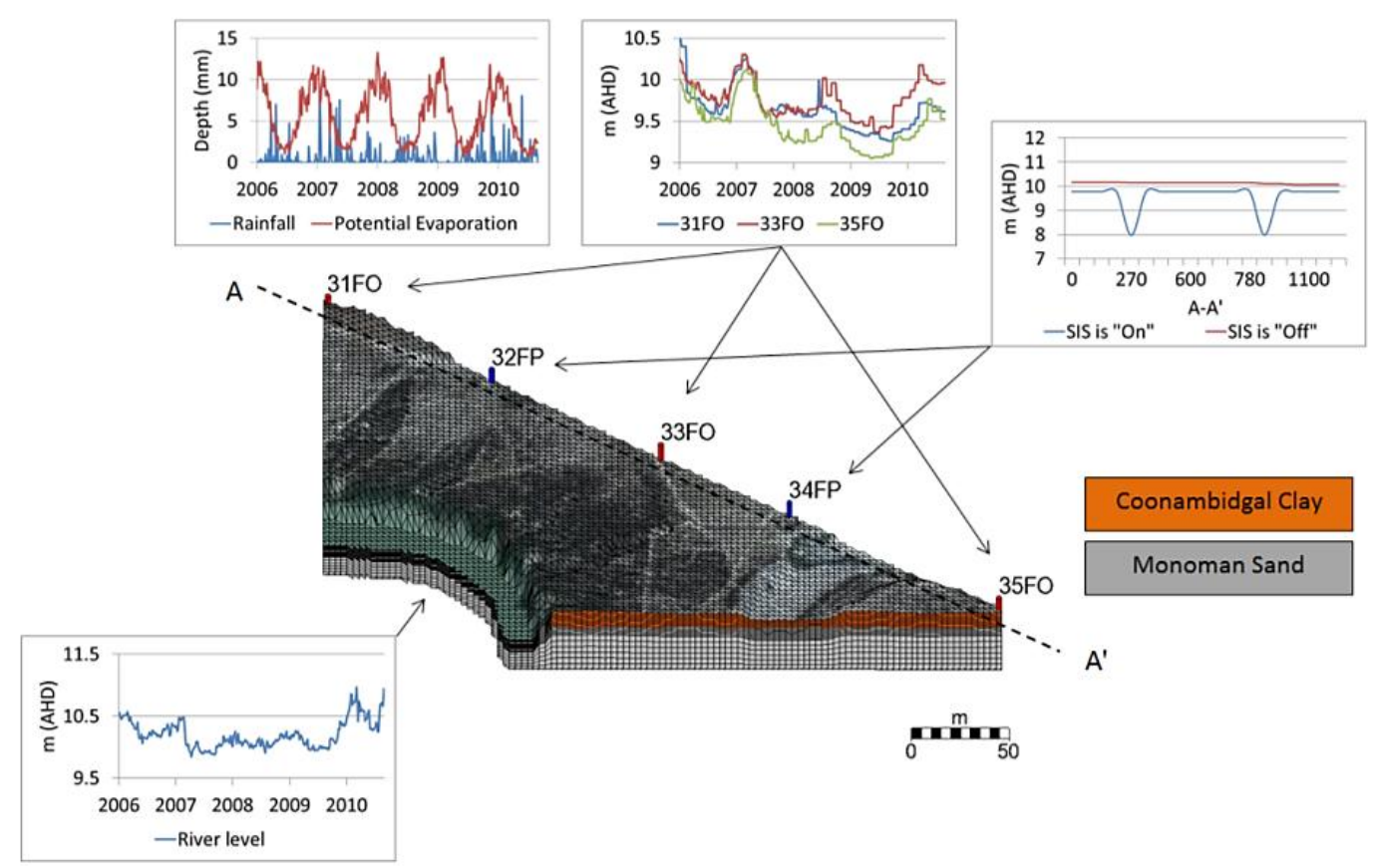

Fig. 3. Configuration of boundary conditions for the river, floodplain and groundwater domains.

Table 1. Porous media and van Genuchten function parameter values.

\begin{tabular}{lrrrrrrrr}
\hline & & & & & & \multicolumn{2}{c}{$\begin{array}{c}\text { Van Genuchten } \\
\text { functions parameters }\end{array}$} \\
\cline { 5 - 10 } & $\begin{array}{r}k \text { isotropic } \\
\left(\mathrm{m} \mathrm{d}^{-1}\right)\end{array}$ & $\begin{array}{r}\text { Specific } \\
\text { storage }\left(\mathrm{m}^{-1}\right)\end{array}$ & $\begin{array}{r}\text { Transverse } \\
\text { dispersivity }(\mathrm{m})\end{array}$ & $\begin{array}{r}\text { Longitudinal } \\
\text { dispersivity }(\mathrm{m})\end{array}$ & $\begin{array}{r}\text { Porosity } \\
\left(\mathrm{m}^{3} \mathrm{~m}^{-3}\right)\end{array}$ & $\begin{array}{r}\text { Alpha } \\
\left(\mathrm{m}^{-1}\right)\end{array}$ & $\begin{array}{r}\text { Beta } \\
(\text { dimensionless })\end{array}$ & $\begin{array}{r}\text { Residual } \\
\text { saturation }\end{array}$ \\
\hline Coonambidgal Clay & 0.1 & 0.002 & 0.5 & 5 & 0.6 & 0.28 & 2.52 & 0.04 \\
\hline Monoman Sand & 20 & 0.00016 & 0.5 & 5 & 0.35 & 1.69 & 8.25 & 0.04 \\
\hline
\end{tabular}

The geometry of the developed model in this study covers the upper $15 \mathrm{~m}$ of the floodplain aquifer that includes two soil types. The overlying Coonambidgal Clay ranges from 2 to $7 \mathrm{~m}$ thick, while the underlying Monoman Sand Formation is approximately $7 \mathrm{~m}$ thick in this area. The cliffs adjacent to the floodplains consist of a layer of Woorinen Sands over Blanchtown Clay, each approximately $2 \mathrm{~m}$ thick, overlying a layer of Loxton Sands up to $35 \mathrm{~m}$ in depth. The whole area is underlain by the Bookpurnong Beds, which act as an aquitard basement to the shallow aquifer that encompasses the Monoman Formation and Loxton Sands (Doble et al., 2006). Saline groundwater lies beneath the floodplain, within the Monoman Formation, with the depth to the water table ranging from 2 to $4 \mathrm{~m}$ below the surface. The majority of the floodplain groundwater has an approximate electrical conductivity of $50000\left(\mu \mathrm{S} \mathrm{cm}^{-1}\right)$. It is worth noting that the physiological limit for water uptake in this environment is $30000\left(\mu \mathrm{Sm}^{-1}\right)$ by river red gums and 55000 $\left(\mu \mathrm{S} \mathrm{m}^{-1}\right)$ by black box trees (Overton and Jolly, 2004). A more detailed description of the study site is discussed by
Brown and Stephenson (1991), Jarwal (1996) and Doble et al. (2006).

\section{Numerical model}

The HydroGeoSphere (HGS) model is capable of simulating fully coupled surface/sub-surface flow and transport. The sub-surface module is based on the University of Waterloo and Université Laval three-dimensional (3-D) subsurface and transport code FRAC3DVS (Therrien, 1992). The surface module is based on the Surface Water Flow Package of the MODHMS simulator, which is itself an enhancement of the popular US Geological Survey code MODFLOW (Brunner and Simmons, 2012). HGS requires pre- and post-processor tools in order to handle input preparation (complex topography and grids) and visualization of the outputs. In this study, a grid builder (McLaren, 2005) and a groundwater modelling system (GMS) (AquaVeo, 2011) were used as preprocessors to generate the input grid domain. Also, the GMS 
was applied as a post-processor to visualize the model results. The next section describes the governing equations of the model. The governing equations of the HGS model are described in Therrien et al. (2010).

\subsection{Model set-up}

The River Murray 2008 stitched digital elevation model (DEM) was one of several outputs delivered through the Imagery Baseline Data Program, completed in late 2008 by the Department for Water of the Government of South Australia. The DEM, completed by CSIRO, is a product of several smaller "River Murray" DEMs, stitched together using GIS methods. The resolution of these DEMs ranges from $2 \mathrm{~m}$ to $50 \mathrm{~m}$ with the final stitched DEM having a resolution of $2 \mathrm{~m}$. Where lidar has been used to acquire data, the vertical accuracy is approximately $\pm 0.15-0.2 \mathrm{~m}$. For this study, the DEM of the study site was generated at a $10 \mathrm{~m}$ grid resolution using lidar data. A $10 \mathrm{~m}$ grid size was used for computational purposes and was adequate to model the processes in the floodplain.

The vertical discretization was chosen to meet the balance between the required computational time and sufficient spatial representation of the two soil layers. Two types of soil layers were present according to the observed drill log data. Hence, a total of 20 sub-layers were considered including finer grids, with 15 sub-layers for the top $5 \mathrm{~m}$, and 5 relatively larger layers for the bottom $10 \mathrm{~m}$. The top 5 sub-layers correspond to Coonambidgal Clay and the lower 15 sub-layers to Monoman Sand. The final geometry grid consisted of 78624 nodes that form 143500 elements. As illustrated in Fig. 3, the geometry grid covers part of Clark's floodplain from the floodplain slope break to the River Murray main channel. This includes two SIS production wells (32FP and 34FP) and nine observation wells. In this case, the length of the river bank was $570 \mathrm{~m}$ and the distance from the river bank to the SIS well varied between $480 \mathrm{~m}$ and $650 \mathrm{~m}$ (Fig. 3).

The properties of the porous media (soil) of the model and unsaturated van Genuchten function parameters (van Genuchten, 1980) are adopted from Jolly et al. (1993) and Doble et al. (2006). They adjusted and proposed van Genuchten functions parameters for the lower River Murray soil types including semi-confining heavy Coonambidgal Clay, Monoman Sand and two forms of transition layer (Table 1). In natural conditions, the hydraulic parameters of the surface domain (river bed and floodplain corridor) have significant differences and so the model was divided into the main channel (river) and the floodplain. Table 2 indicates the values of the surface properties of the numerical model (Therrien et al., 2005). During the time frame of the model no flow above the river bank occurred (i.e. only non-flooding conditions occurred) and so the model results are insensitive to the surface properties.

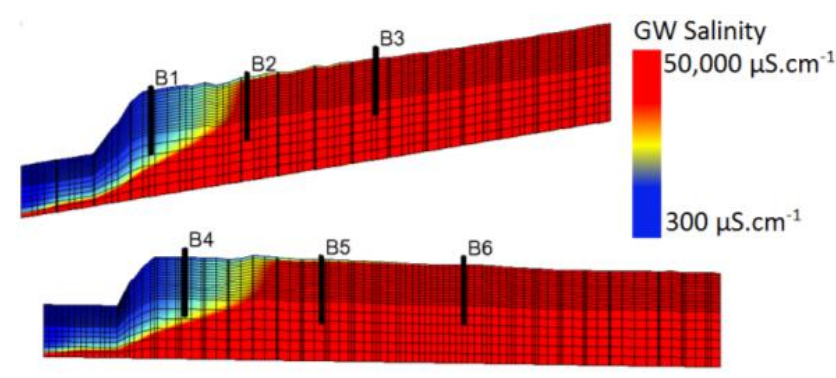

a.

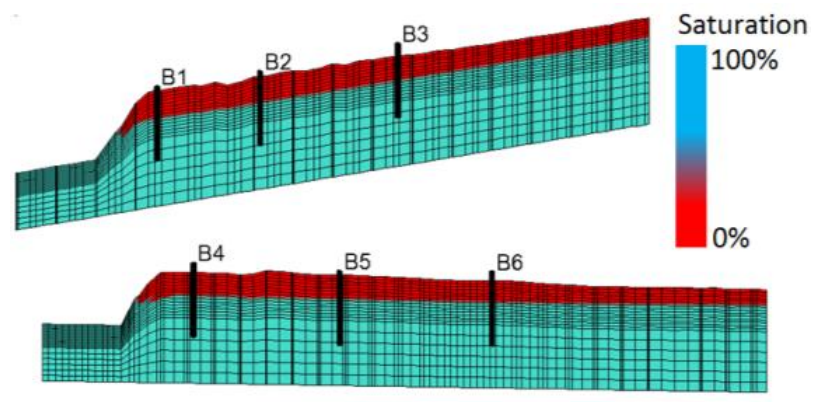

b.

Fig. 4. 3-D demonstration of simulated initial condition along transects B1 and B2: (a) porous media saturation, (b) solute concentration distribution. Observation wells are in black.

ET is one of the main drivers of the hydrological processes occurring in an arid/semi-arid region such as the lower River Murray (Doble et al., 2006; Holland et al., 2009a). The two main vegetation types occurring at the study site (Eucalyptus tree and grass) have significantly different characteristics in terms of root depth, water demand and leaf area index. In order to obtain a better representation of the actual conditions, vegetation coverage of the floodplain was classified into two different categories. Normalized evaporation and root depth functions were mapped onto porous media elements above the maximum depths. Currently, four evaporation and root depth functions are available in HGS; constant, linear, quadratic and cubic. In this study, quadratic evaporation and root depth functions were applied. Table 3 shows the values of the ET components for Eucalyptus and grass adopted from Hingston et al. (1997), Banks et al. (2011) and Verstrepen (2011).

The boundary conditions for the numerical model of the study site included specified head boundaries in the porous domain which were implemented at the end of the floodplain. In this case, observed groundwater heads at the location of the $31 \mathrm{FO}, 33 \mathrm{FO}$ and $35 \mathrm{FO}$ were assigned to nodes along the model edge as shown in Fig. 3. On the other hand, specified heads were used to lower the water table at the location of the 32FP and 34FP consistent with their recorded pumping rates. Observed river levels for the surface domain were set at the river side of the model using specified heads. In 
Table 2. Surface properties values of the numerical model.

\begin{tabular}{lrrrrrrr}
\hline & $x$ friction & $y$ friction & $\begin{array}{r}\text { Rill storage } \\
\text { height }(\mathrm{m})\end{array}$ & $\begin{array}{r}\text { Obstruction storage } \\
\text { height }(\mathrm{m})\end{array}$ & $\begin{array}{r}\text { Coupling } \\
\text { length }(\mathrm{m})\end{array}$ & $\begin{array}{r}\text { Longitudinal } \\
\text { dispersivity }(\mathrm{m})\end{array}$ & $\begin{array}{r}\text { Transverse } \\
\text { dispersivity }(\mathrm{m})\end{array}$ \\
\hline River & 0.005 & 0.005 & 0.0001 & 0 & 0.01 & 1 & 1 \\
\hline Floodplain & 0.05 & 0.05 & 0.01 & 0.001 & 0.01 & 1 & 1 \\
\hline
\end{tabular}
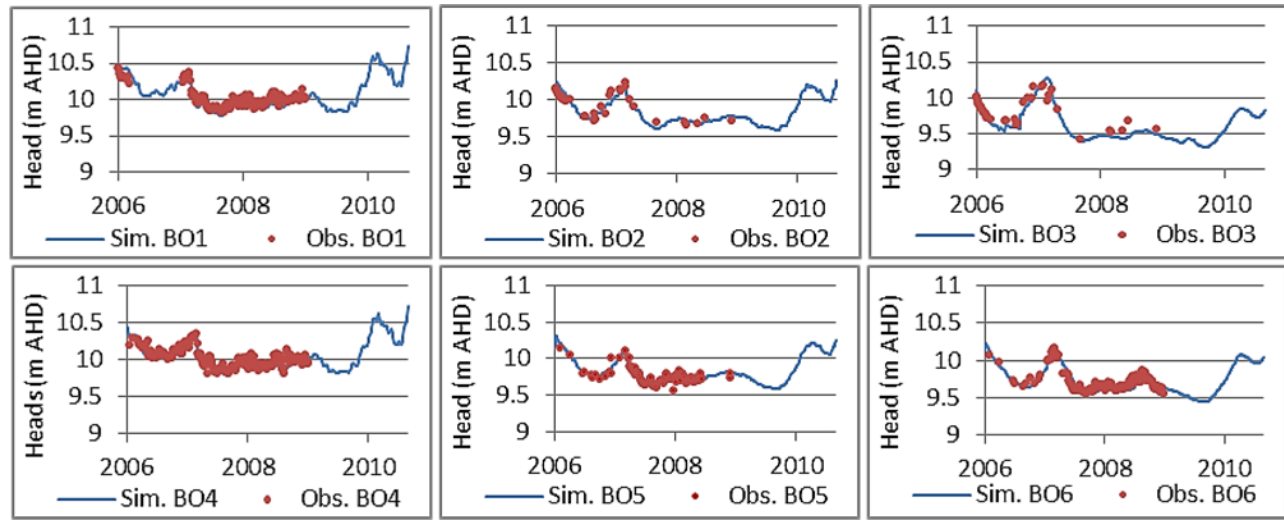

Fig. 5. Simulated and observed groundwater heads at observation wells.

Table 3. ET component parameters values for the study site.

\begin{tabular}{lrr}
\hline & Eucalyptus & Grass \\
\hline Canopy storage parameter $(\mathrm{m})$ & 13.9 & 22.8 \\
Initial interception storage $(\mathrm{m})$ & 0.00045 & 0.0004 \\
\hline Transpiration fitting & & \\
C1 & 0.3 & 0.6 \\
C2 & 0.2 & 0 \\
C3 & 1 & 1 \\
\hline Transpiration limiting saturations & & \\
wilting point & 0.29 & 0.29 \\
field capacity & 0.56 & 0.56 \\
oxic limit & 0.85 & 0.75 \\
anoxic limit & 0.95 & 0.9 \\
\hline Evaporation limiting saturations & 0.22 & 0.25 \\
& 0.95 & 0.9 \\
LAI & 0.5 & 0.5 \\
\hline Root depth (m) & 5 & 0.5 \\
\hline Evaporation depth (m) & 1 & 1 \\
\hline
\end{tabular}

this regard, the observed water levels downstream of Lock 4 [ID: A42260515] (WaterConnect, 2013) were applied to the river nodes of the model. In addition, rainfall was simulated for the entire model surface domain beginning on day 1. ET was dynamically simulated as a combination of evaporation and transpiration processes by removing water from all model cells of the surface and sub-surface flow domains
Table 4. Results of the calibrated model performance statistics.

\begin{tabular}{lrrrr}
\hline Observation wells & $R^{2}$ & $N_{\mathrm{r}}$ & MSR (m) & RMSE (m) \\
\hline BO1 & 0.91 & 0.76 & 0.054 & 0.067 \\
BO2 & 0.87 & 0.71 & 0.075 & 0.088 \\
BO3 & 0.85 & 0.657 & 0.080 & 0.091 \\
BO4 & 0.83 & 0.77 & 0.044 & 0.058 \\
BO5 & 0.83 & 0.63 & 0.031 & 0.041 \\
BO6 & 0.81 & 0.61 & 0.048 & 0.061 \\
\hline
\end{tabular}

within the defined zone of the evaporation and root extinction depths. The daily rainfall and potential evaporation values used in the model were based on recorded daily rainfall at the Loxton station [ID: 024024] (BOM, 2013). To represent the solute boundary conditions, first-type (Dirichlet) or constant concentration boundary conditions were assigned. Observed groundwater TDS concentrations at the observation wells in the floodplain and river ranged from $30000 \mathrm{mg} \mathrm{L}^{-1}$ to $200 \mathrm{mg} \mathrm{L}^{-1}$. Hence, constant values were applied at the porous media boundary (representing the regional saline aquifer) and the river nodes accordingly. Figure 3 illustrates the configuration of all boundary conditions in the model.

Initial conditions refer to the head and solute concentration distributions throughput the model at the beginning of the simulation. In this context, field-measured head values or solute concentrations do not represent the real initial condition as they are obtained at a time when the natural groundwater system is in equilibrium (Barnett et al., 2012). For 

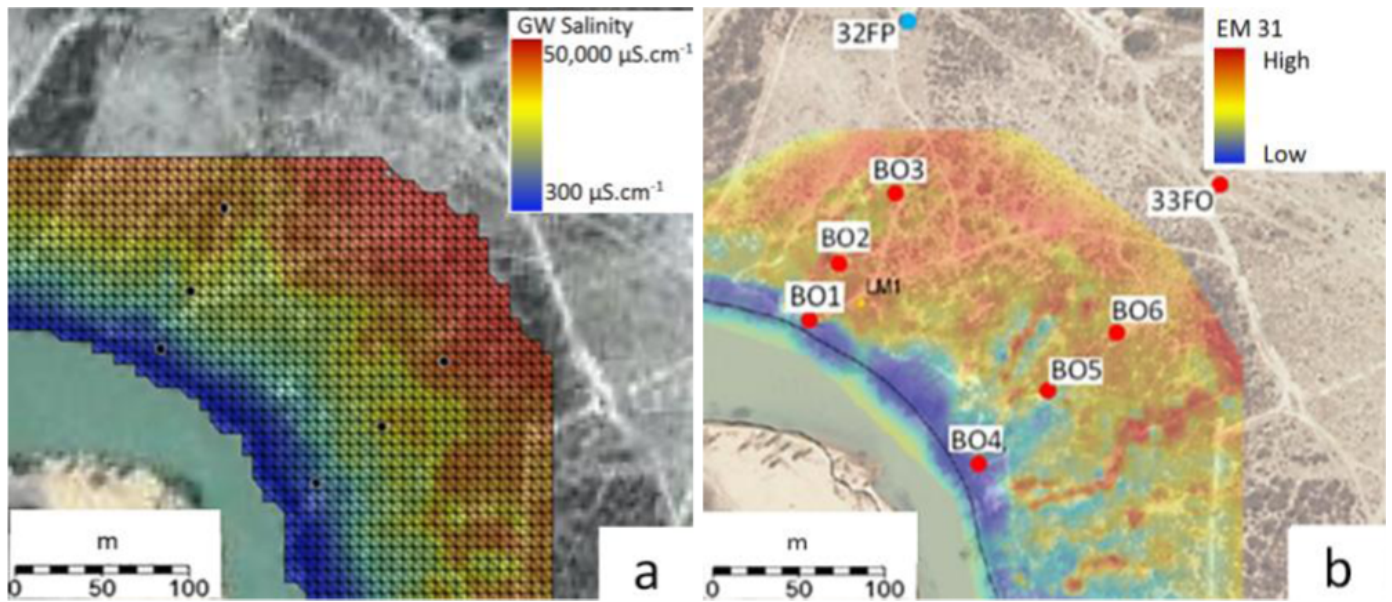

Fig. 6. Simulated solute concentration distribution (a) and EM31 survey (Berens et al., 2009) (b) in November 2007 at the study site.

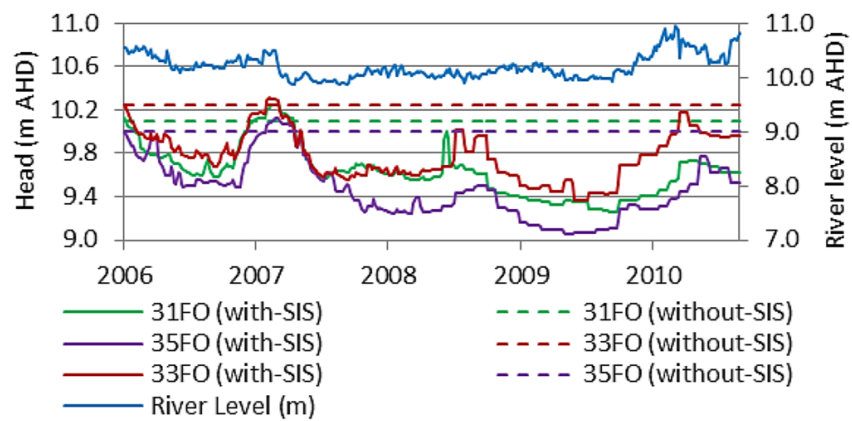

Fig. 7. Groundwater heads at the boundary of the models (SIS wells) for the defined scenarios.

instance, if the field-observed data values are used as initial conditions, the model response in the early time steps would reflect not only the model stress under study but also the adjustment of model head values to offset the lack of correspondence between model hydrologic inputs and parameters and the initial head values (Franke et al., 1987). Therefore, in a transient state problem, the initial conditions should be determined through a steady/dynamic steadystate solution to generate dynamic cyclic initial conditions such as evaporation and rainfall seasonal cycles (Anderson and Woessner, 1992). Barnett et al. (2012) suggested carrying out a simulation which begins long enough before the calibration period allowing for an initial model equilibration time. In this study, the stress period starts from 1 January 2006 and ends on 1 September 2010. So, the initial model covers a $30 \mathrm{yr}$ period to create the equilibrium initial condition for the stress period. The initial model was intended to show equilibrium behaviour while its last time steps should be equal to the first time steps of the stress model which are observed (Fig. 4). Hence, simulated groundwater heads are compared with absolute observed values at observation wells (BO1: 10.4, BO2: 10.15, BO3: 10.01, BO4: 10.20, BO5: 10.14 and BO6: 10.07 mAHD; Holland et

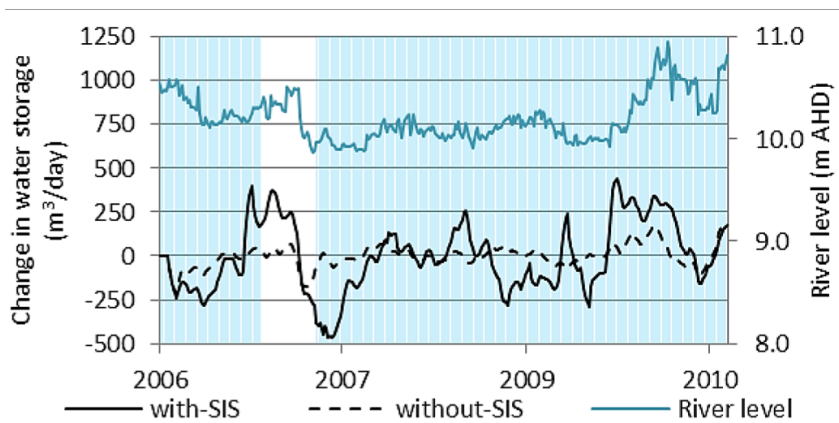

Fig. 8. Changes in water storage in the porous media for the defined scenarios (light blue pattern refers to the period that the pumps were in operation).

al., 2009b). Also, the status of the solute concentration distribution at the beginning of the study (stress) period was checked with the general solute distribution pattern at the floodplain which was observed in the field and in related reports. This can be considered as two zones; a relatively fresh groundwater zone within $50 \mathrm{~m}$ distance of the river banks (BO1: $6500 \mu \mathrm{S} \mathrm{cm}^{-1}$ and BO4: $1200 \mu \mathrm{S} \mathrm{cm}^{-1}$ ) and a saline zone (BO2: $53000 \mu \mathrm{S} \mathrm{cm}^{-1}$, BO3: $54000 \mu \mathrm{S} \mathrm{cm}^{-1}$, BO5: $50900 \mu \mathrm{S} \mathrm{cm}^{-1}$ and BO6: $52000 \mu \mathrm{S} \mathrm{cm}^{-1}$ ) for the rest of the floodplain (Holland et al., 2009b).

\subsection{Coupled flow and transport calibration}

The observed hydraulic heads and groundwater solute concentrations at the observation wells are used as calibration criteria during coupled flow-and-transport calibration of the model (Barnett et al., 2012). This process aims to assess the ability of the surface-groundwater model to correctly distribute water and solute between the two domains ( $\mathrm{Li}$ et al., 2008). Two different approaches were employed for the flow and solute dynamics calibrations. The flow dynamic was calibrated against the absolute observed groundwater levels 


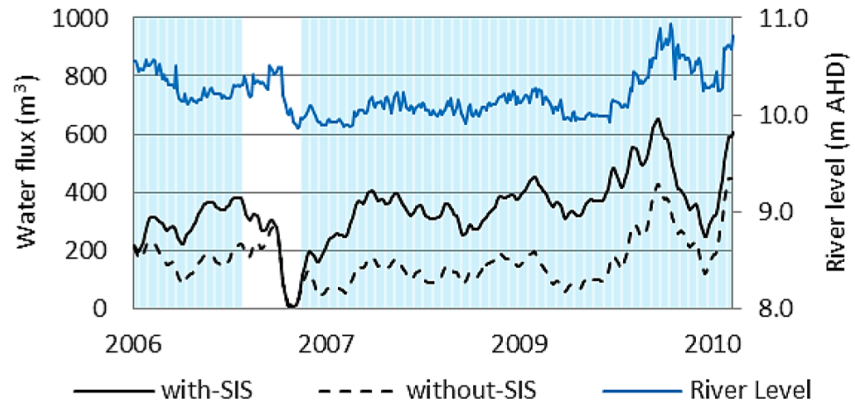

Fig. 9. Water flux from the river to the floodplain aquifer for the defined scenarios (light blue pattern refers to the period that the pumps were in operation).

at the observation wells. But for the solute dynamic, given the difficulty associated with the quantification of the solute transport model parameters, the solute was calibrated to the observed general salinity patterns of the floodplain aquifer. This was because concentration patterns are much more sensitive to local-scale geological heterogeneity than are hydraulic heads, and models may have difficulty reproducing the concentrations or their temporal variability at single observation wells. The general floodplain aquifer solute distribution was obtained from the EM31 surveys adopted from Berens et al. (2009). Hence, in this case, because of significant salinity differences between $50 \mathrm{~m}$ distance to the river bank (BO1 and $\mathrm{BO} 4: \mathrm{EC}<5000 \mu \mathrm{S} \mathrm{cm}^{-1}$ ) and the rest of the floodplain $(\mathrm{BO} 2, \mathrm{BO} 3, \mathrm{BO} 5$ and $\mathrm{BO} 6: \mathrm{EC}=30000$ $50000 \mu \mathrm{S} \mathrm{cm}^{-1}$ ), an aggregate quantity like the plume mass is a more suitable calibration criterion, as recommended by Barnett et al. (2012).

Calibration of the model was conducted manually with more consideration to the sensitive parameters including soil hydraulic conductivity, porosity and dispersivity. The model performance for both flow and solute transport was tested by visual comparison between observed and simulated series of hydraulic heads and solute concentrations at observation wells $\mathrm{BO} 1, \mathrm{BO} 2, \mathrm{BO} 3, \mathrm{BO} 4, \mathrm{BO} 5$ and BO6. Moreover, quantitative evaluation was undertaken using goodness-of-fit measures. Figure 5 demonstrates the performance of the calibrated model of Clark's floodplain. Seeking to optimise the goodness-of-fit by minimizing errors between the observed and simulated values, or to achieve a specific predefined value of goodness-of-fit, may be the best way to increase confidence in predictions (Barnett et al., 2012). The goodnessof-fit measures, including root r-square $\left(R^{2}\right)$, Nash-Sutcliffe $(\mathrm{Nr})$, mean sum of residuals (MSR) and root mean squared error (RMSE), are used to evaluate the simulated values against the observed data (Table 4). Moreover, the solute concentration distribution results show that the calibrated model was able to reproduce the surface-groundwater interaction processes in an acceptable manner, as they present a good agreement. For instance, the EM31 survey in November 2007

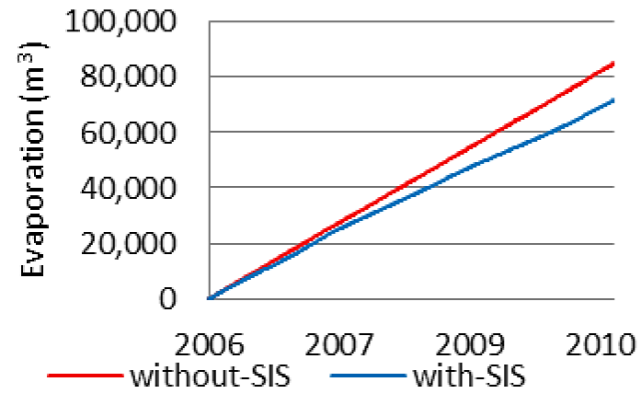

Fig. 10. Cumulative evaporation from the floodplain aquifer for the defined scenarios.

(Fig. 6a) showed a distinct zone of low conductivity along the eastern margin abutting the river channel. This shows the presence of freshwater within the floodplain aquifer (bank storage) and this was supported by groundwater salinity data collected at the riverbank piezometers at that time.

\section{Results and discussion}

Often the objectives of numerical modelling involve a quantitative assessment of the response of heads or solute concentrations to future stresses on the surface or sub-surface system. Predictive scenarios can be formulated to quantify groundwater behaviour in either absolute or relative terms. In the case of the latter, the particular modelling outcome is obtained by subtracting one model result from another (null scenario). A null scenario is a predictive model that has no future changes in the stresses that are being investigated. Considering the prediction approach suggested in the Australian groundwater modelling guidelines (Barnett et al., 2012), even though it may be difficult to calibrate the surface-groundwater interaction model, there may be reasonable confidence in a model to predict the right trends. In these situations, it is not common practice for one set of predictions to be made using the best possible model, and for further predictions to be presented in absolute terms. In this case, to investigate the surface-groundwater interactions induced by groundwater lowering, the calibrated model (20062010) was used as the null scenario without further parameter changes to investigate both the water balance and the solute mass balance. It should be noted that the results discussed here are from a calibrated numerical model based on available data that may include some uncertainties particularly in terms of solute dynamics. Figure 7 shows the groundwater heads at the boundary of the models (SIS wells) for the defined scenarios. In the without-SIS scenario there are constant values equal to $10.1 \mathrm{~m}$ for $31 \mathrm{FO}, 10.25 \mathrm{~m}$ for $33 \mathrm{FO}$ and $10.01 \mathrm{~m}$ for $35 \mathrm{FO}$ (observed just before commencement of the SIS production wells). This assumes that no significant groundwater head changes occurred, while for the withSIS scenario the heads are influenced by the SIS production 

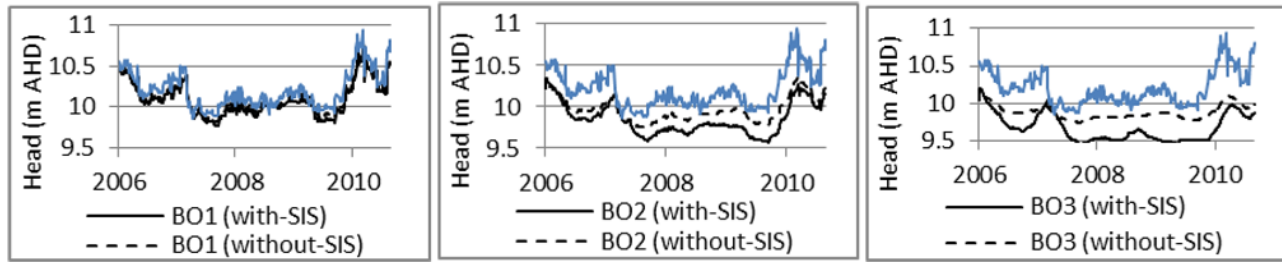

Fig. 11. Groundwater head dynamics at the observation wells on transect B1 for the with-SIS and the without-SIS scenarios.
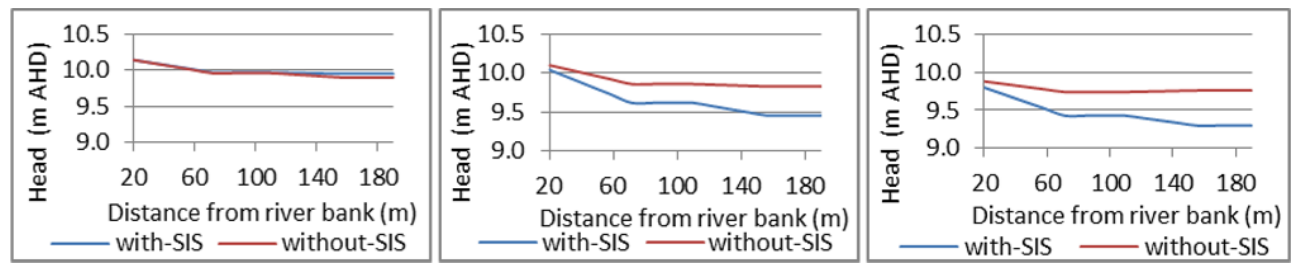

Fig. 12. Groundwater head longitudinal profiles on 7 March 2007 (left), 16 November 2008 (middle) and 29 July 2009 (right) on transect B2 for the with-SIS and the without-SIS scenarios.

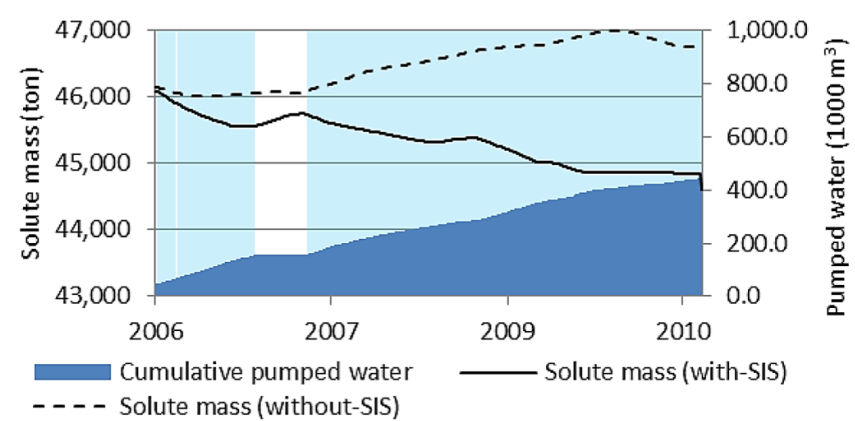

Fig. 13. Solute mass stored in the system in each time step for the defined scenarios. Cumulative pumped water is also shown in dark blue, and light blue pattern refers to the period that the pumps were in operation.

wells. In this paper, a losing floodplain regime corresponds to a movement of flow from the floodplain aquifer to the river and a gaining floodplain regime refers to flow movement from the river to the floodplain aquifer. Conversely, a losing river regime refers to movement of flow from the river to the floodplain aquifer and a gaining river shows flow movement from the floodplain aquifer to the river.

\subsection{Water balance}

One of the main starting points for analysis of the flow dynamics in a surface-groundwater system is accurate modelling of the water balance. In this case, three forms of water balance outputs are considered as indicators to compare the scenarios. These indicators include changes in water storage in the porous and/or overland domain, the amount of water movement between the two domains (flow flux) and the groundwater head profile along the observation transects.
Hence, three outputs of the model are considered in the analysis of the system water balance including the change in water storage (In-Out) in the porous medium $\left(\mathrm{m}^{3} \mathrm{day}^{-1}\right)$, the water flux $\left(\mathrm{m}^{3}\right)$ from the river to the floodplain aquifer and the groundwater head profile along transect B1.

The change in water storage in the floodplain aquifer is shown in Fig. 8. The change in water storage for the withoutSIS scenario shows a relatively balanced trend during the study period. A correlation between the change in water storage and the river water level fluctuation are observed. This is because as the river water level increases, it increases as more water is stored in the floodplain aquifer. In contrast, a river water level decrease leads to negative value as less water enters the floodplain aquifer in comparison with the water that leaves. Note that in this study a constant groundwater head is applied (assuming no significant changes in groundwater head) as the boundary condition for the without-SIS scenario. This is why the accumulation rate corresponds significantly to the river water level fluctuations. For the with-SIS scenario, a clear connection between the groundwater head fluctuations due to groundwater extraction and the change in water storage can be seen, with an increase in change in water storage corresponding to an increase in groundwater head. In this scenario, it seems that the groundwater lowering (due to the extraction) is the main driver rather than river water level changes. In other words, when the SIS production wells are in operation, groundwater heads decline due to extraction and this leads to negative value. But, when the SIS production wells stop working (no extraction), the groundwater heads increase as the floodplain aquifer is recharged by the river and the highland groundwater. This leads to a positive value for the change in water storage. Another explanation for this process can be a change of floodplain groundwater regime from losing (due to groundwater extraction through the SIS 

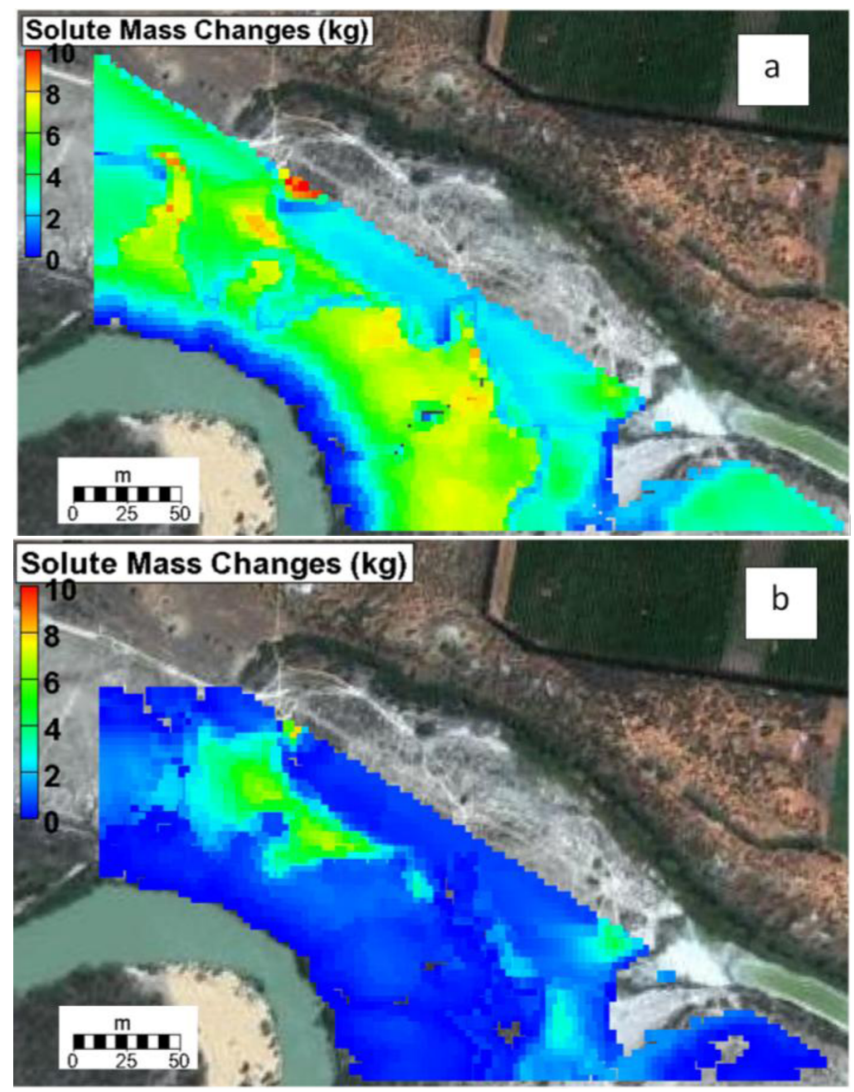

Fig. 14. 3-D visualization of solute mass changes in the unsaturated zone for the defined scenarios; (a) amount of solute mass removed from the unsaturated zone during the with-SIS scenario, (b) amount of solute mass that could be stored in the system if SIS was not installed on the floodplain.

production wells) to gaining (due to groundwater recharge). This shows that the river water level fluctuation is not the dominant driver in this situation; otherwise, an increase in accumulation rate would have occurred during the operation of the SIS production wells when the floodplain aquifer was in a losing regime.

Figure 9 shows the amount of water that moved from the river to the floodplain aquifer during the study period for the defined scenarios, and this is clearly related to the river water level. In other words, the amount of water that moves from the river to the floodplain aquifer increases with increasing river water levels and vice versa. This shows that for the study site there is a good connection between the river and the floodplain aquifer through bank recharge. On the other hand, the general trend in both scenarios is almost the same, although the amount of flux from the river to the floodplain aquifer is relatively higher for the with-SIS scenario. This is attributed to the operation of the SIS production wells that creates a groundwater gradient away from the river. In the with-SIS case, fresh river water is drawn towards the SIS production wells, which may result in a relatively fresher floodplain aquifer. It is worth noting that in a high river level condition, which occurred at the end of the study period, a smaller difference in the flux is observed. This means that in high flow situations the amount of flux is too high for groundwater extraction (at least at this scale) to make a significant difference. Also, when the SIS was shut down from November 2006 to May 2007, the flux from the river to the floodplain was the same.

Following the SIS commencement in July 2005, a water table gradient away from the river developed with the groundwater level at observation well BO3 being up to $0.5 \mathrm{~mm}$ below the observed river level. From June to November 2006, under relatively stable river levels, observations indicate a groundwater gradient away from the river between $\mathrm{BO} 1$ (at the riverbank) and $\mathrm{BO} 3$ of $0.4 \mathrm{~m}$ over a distance of $130 \mathrm{~m}$. During the SIS shutdown from November 2006 to May 2007, the groundwater levels across Transect B1 indicated a reduced gradient with $\mathrm{BO} 1, \mathrm{BO} 2$, and $\mathrm{BO} 3$ at similar elevations. Monthly means of the $\mathrm{BO} 1$ groundwater level hydrograph indicate groundwater elevations were greater than river levels during February, March and April 2007, indicating gaining stream conditions with the B1 and the SIS midpoint hydrographs above the recorded river level. Following the reinstatement of the SIS in May 2007, recorded levels in the Transect B1 wells indicate that a losing stream gradient was rapidly restored and maintained in the absence of further SIS stoppages. In terms of the evaporation, Fig. 10 shows that the cumulative amount of water which left the system via the evaporation in the without-SIS scenario was around $18 \%$ larger than for the with-SIS case. This may be due to the increased groundwater level in the without-SIS scenario which provides more water that is available to be evaporated.

The dynamic of the floodplain groundwater as a hydrograph and as a longitudinal profile along transects B1 and B2 are shown in Figs. 11 and 12, respectively. In Fig. 11, the impact of groundwater lowering due to the SIS production wells is much more significant at the end of the floodplain (BO3) compared to at the river bank (BO1). The only times that the two defined scenarios show the same groundwater heads are when the SIS production wells stopped working (from November 2006 to May 2007). For instance, in March 2007 the groundwater head increased to its normal level (equal to the without-SIS scenario). Given the river water level fluctuations and the groundwater responses, it can be seen that in the without-SIS scenario, river water level change is the main driver of the surface-groundwater processes. Hence, the floodplain aquifer near the river bank (BO1) is more sensitive to river water level changes compared to further away from the river bank (BO2 and $\mathrm{BO} 3)$. In the with-SIS scenario, it is groundwater lowering induced by the SIS production wells that has more influence on the system. Figure 12 shows three longitudinal profiles of the floodplain aquifer groundwater head. Again, areas further away from the river banks are more influenced by the SIS production wells and these influences become more significant during the SIS operation periods. 

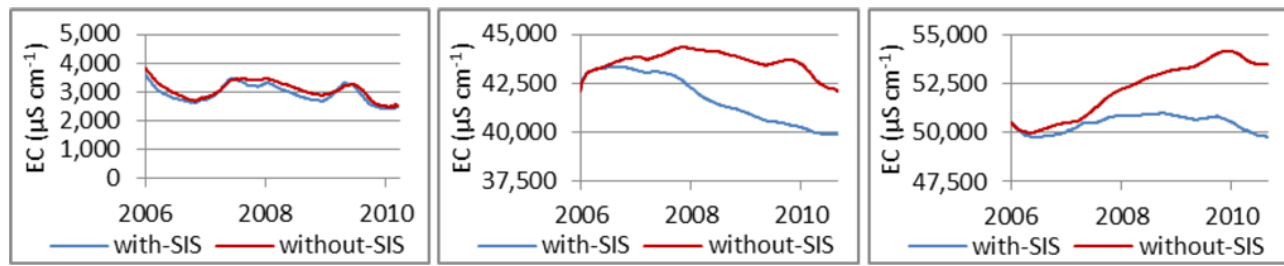

Fig. 15. Solute dynamics at the observation wells BO1 (left), BO2 (middle) and BO3 (right).

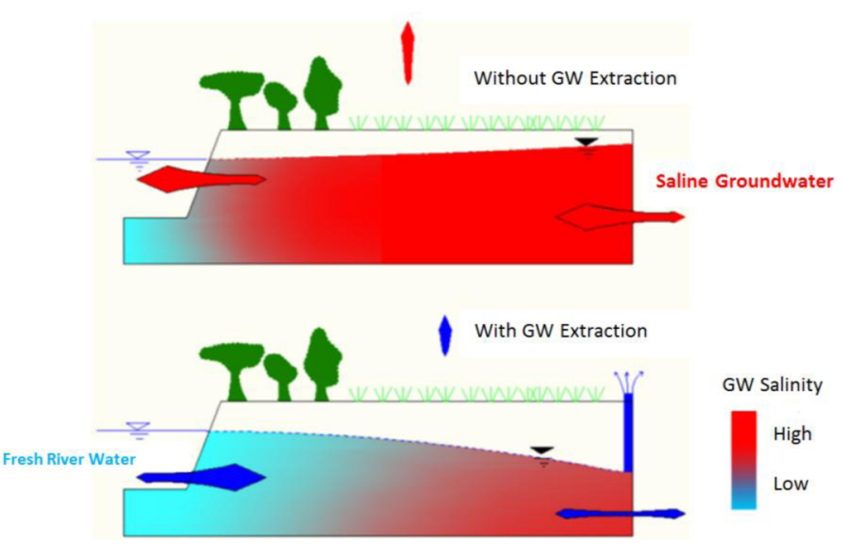

Fig. 16. Conceptual model of the impacts of groundwater extraction on salinization risk in a semi-arid floodplain.

\subsection{Solute mass balance}

Figure 13 shows the temporal trend of the total amount of solute mass stored in the system. The without-SIS scenario leads to a more saline floodplain aquifer, and also the amount of solute mass stored in the floodplain aquifer increases with time. In contrast, salinity levels were reduced for the withSIS scenario with the exception of the period of time when the SIS was shut down. In fact, this was due to an increased flux of fresher river water induced by the SIS, in addition to the removal of saline groundwater and reduced saline groundwater flux to the floodplain from the highland. This is consistent with the field observations of Berens et al. (2009) and Holland et al. (2009b) at the same study site. According to these results, the total solute mass stored in the system in the with-SIS scenario reduces by up to $4 \%$ (1680 tonnes) while the without-SIS scenario shows a $2 \%$ (846 tonnes) increase. Depending on the scale of the model, these values can be considerable. It is worth noting that in the withoutSIS scenario, there is a relative decline in solute mass in the system at the end of the study period. This is due to the occurrence of high river flows and overbank flows that took place just after the study period. Hence, in that short period, solute accumulation decreased and relatively less solute mass was stored in the system.
The unsaturated zone may act as an essential component of the solute mass stored in the floodplain aquifer, particularly in an area such as the study site where salinity is driven by increased discharge of saline groundwater and reduced leaching of salts from the soils. A high rate of ET can accelerate this process. According to the results, at the last time step 7120 tonnes solute mass was stored in the unsaturated zone of the without-SIS model. The corresponding value for the with-SIS model for the same time step was 5562 tonnes. This proves that the groundwater extraction is able to remove a significant amount of solute stored in the unsaturated zone. It is worth noting that this model was up to $16 \mathrm{~m}$ in depth but shallower models might produce different proportions of unsaturated zone storage. Figure 14 illustrates the solute mass changes in the unsaturated zone for the defined scenarios. In Fig. 14a the distribution of solute mass removed from the unsaturated zone is shown. Groundwater extraction via the SIS operation removed solute mainly from the middle part of the floodplain. Figure 14b shows the amount of solute mass that could be stored in the system if the SIS was not installed on the floodplain. In fact, without groundwater extraction more solute could have been stored in the floodplain aquifer. This is consistent with the results in Fig. 13 which show that groundwater extraction may lead to a less saline floodplain as well as less solute mass storage in the unsaturated zone.

The dynamic of groundwater salinity is demonstrated in Fig. 15. It appears that at the relatively fresh buffer zone near the river bank, the groundwater salinity is almost the same in both scenarios. Away from the river bank, towards the SIS production wells, the influence of the SIS production wells can be clearly seen. The groundwater salinity slightly increases during the study period in the without-SIS scenario while in the other scenario the ability of the SIS operation to mitigate the salinity is significant. Again, the influence is stronger in the floodplain than at distances closer to the river bank. However, in this case, groundwater extraction is not able to change the overall pattern of the salinity of the floodplain aquifer. Since even with the SIS operation there is a dramatic difference in salinity between the river bank (less than $5000 \mu \mathrm{S} \mathrm{cm}^{-1}$ ) and the floodplain (above $40000 \mu \mathrm{S} \mathrm{cm}^{-1}$ ) and the decrease in salinity due to the SIS is of the same order. 


\section{Conclusions}

The relative impacts of saline groundwater extraction on the interactions between a river and its adjacent semi-arid floodplain have been investigated. A 3-D fully integrated physically based numerical model was used to simulate two defined scenarios, namely with and without SIS. The numerical model was first calibrated using observed data. The results showed a reasonable correlation between observed and simulated values. The model was able to effectively reproduce the surface-groundwater interactions. Then the calibrated model was used to simulate the defined without-SIS scenario. A conceptual model of the impact of groundwater extraction on floodplain salinization is shown in Fig. 16.

Water balance analysis showed that groundwater extraction may change the floodplain aquifer regime from losing to gaining (or at least to reduce the losing rate). This happens by changing the head gradient towards the floodplain. This can lead to a higher amount of fresh river water flux to the saline floodplain aquifer and a wider freshwater lens along the riparian vegetation at the river bank. Also, a deeper water table is observed as a result of groundwater extraction. This is more significant in the area around the production wells in the floodplain rather than closer to the river banks. In the without-SIS scenario it is the river water fluctuations that dominate the surface-groundwater interactions while in the with-SIS scenario, the groundwater extraction is the main driver. Moreover, more groundwater has been removed from the floodplain aquifer via evaporation in the without-SIS scenario.

In terms of the solute balance, the SIS results in a less saline floodplain aquifer, as evidenced by the reduced amount of solute stored in the with-SIS scenario. Moreover, it was shown that groundwater extraction is able to remove significant proportions of the solute mass from the unsaturated zone. Overall, the saline groundwater extraction from the floodplain aquifer is shown to be an effective salt interception measure. This occurs through three mechanisms, namely extraction of the solute mass from the system, reducing the saline groundwater flux from the highland to the floodplain and changing the floodplain groundwater regime from a losing to a gaining one. The latter may result in more flux from the river to the floodplain aquifer. The current management of the SIS operation seems to be effective in maintaining the floodplain salinity at a stable level.

Acknowledgements. This work was supported by the Goyder Institute for Water Research. The authors would like to acknowledge the assistance and scientific support of Ian Jolly, Kate Holland and Rebecca Doble (CSIRO), Volmer Berens (DENWR), and Adrian Werner, Juliette Woods, James McCallum and Dylan Irvine (Flinders University).

Edited by: P. Tarolli

Reviewed by: A. Tolooiyan and one anonymous referee

\section{References}

Abbott, M. B., Bathurst, J. C., Cunge, J. A., O’Connell, P. E., and Rasmussen, J.: An introduction to the European Hydrological System-Syst'eme Hydrologique Européen, SHE, 2: Structure of a physically-based distributed modeling system, J. Hydrol., 87, 61-77, 1986.

Allison, G. B., Cook, P. G., Barnett, S. R., Walker, G. R., Jolly, I. D., and Hughes, M. W.: Land clearance and river salinization in the western Murray Basin, Australia, J. Hydrol., 119, 1-20, 1990.

Anderson, M. P. and Woessner, W. W.: Applied groundwater modelling: simulation of flow and advective transport, Academic Press, San Diego, USA, 1992.

AquaVeo: GMS, Provo, UT, 2011.

Banks, E. W., Brunner, P., and Simmons, C. T.: Vegetation controls on variably saturated processes between surface water and groundwater and their impact on the state of connection, Water Resour. Res., 47, W11517, doi:10.1029/2011WR010544, 2011.

Barnett, B., Townley, L. R., Post, V., Evans, R. E., Hunt, R. J., Peeters, L., Richardson, S., Werner, A. D., Knapton, A., and Boronkay, A.: Australian groundwater modelling guidelines, National Water Commission, Canberra, 2012.

Berens, V., White, M., and Souter, N.: Bookpurnong Living Murray Pilot Project: A trial of three floodplain water management techniques to improve vegetation condition, Department of Water, Land and Biodiversity Conservation, Adelaide, 2009.

Beven, K.: On explanatory depth and predictive power, Hydrol. Process., 15, 3069-3072, 2001.

Beven, K.: Towards a coherent philosophy for modelling the environment, Proc. Roy. Soc. A, 458, 2465-2484, 2002.

Beven, K.: A manifesto for the equifinality thesis, J. Hydrol., 320, 18-36, 2006.

Beven, K. and Binley, A.: The future of distributed models: model calibration and uncertainty prediction, Hydrol. Process., 6, 279298, 1992.

BOM: Climate data online, available at: http://www.bom.gov.au, last access: 11 April 2013.

Brown, C. M. and Stephenson, A. E.: Geology of the Murray Basin, Southeastern, Bureau of Mineral Resources, Canberra, 1-22, 1991.

Brunner, P. and Simmons, C. T.: HydroGeoSphere: A Fully Integrated, Physically Based Hydrological Model, Ground Water, 50, 170-176, 2012.

Brutsaert, W. and Lopez, J. P.: Basin-scale geohydrologic drought flow features of riparian aquifers in the southern Great Plains, Water Resour. Res., 34, 233-240, 1998.

Camporese, M., Paniconi, C., Putti, M., and Orlandini, S.: Surfacesubsurface flow modeling with path-based runoff routing, boundary condition-based coupling, and assimilation of multisource observation data, Water Resour. Res., 46, W02512, doi:10.1029/2008WR007536, 2010.

Chen, X.: Stream water infiltration, bank storage, and storage zone changes due to stream-stage fluctuations, J. Hydrol., 280, 246264, 2003.

Chen, X. and Shu, L.: Groundwater evapotranspiration captured by seasonally pumped wells in river valleys, J. Hydrol., 318, 334347, 2006.

Doble, R.: Quantifying spatial distributions of groundwater discharge and salt accumulation on a semi-arid floodplain to determine vegetation health response, $\mathrm{PhD}$, School of Chemistry, 
Physics and Earth Sciences, Flinders University of South Australia, Adelaide, 371 pp., 2004.

Doble, R., Simmons, C., Jolly, I., and Walker, G.: Spatial relationships between vegetation cover and irrigation-induced groundwater discharge on a semi-arid floodplain, Australia, J. Hydrol., 329, 75-97, doi:10.1016/j.jhydrol.2006.02.007, 2006.

DWR: South Australian River Murray Salinity Strategy 2001-2015, Department for Water Resources, Government of South Australia, Adelaide, 2001.

Ebel, B. A. and Loague, K.: Physics-based hydrologic-response simulation: Seeing through the fog of equifinality, Hydrol. Process., 20, 2887-2900, 2006.

Franke, O. L., Reily, T. E., and Bennett, G. D.: Definition of boundary and initial conditions in the anaysis of saturated ground-water flow systems; an introduction, USGS, Washington, 1-22, 1987.

Freeze, R. A. and Harlan, R. L.: Blueprint for a physically-based, digitally-simulated hydrologic response model, J. Hydrol., 9, 237-258, 1969

Hart, B., Bailey, P., Edwards, R., Hortle, K., James, K., McMahon, A., Meredith, C., and Swadling, K.: A review of the salt sensitivity of the Australian freshwater biota, Hydrobiologia, 210, 105-144, 1991.

Herczeg, A. L., Simpson, H. J., and Mazor, E.: Transport of soluble salts in a large semiarid basin: River Murray, Australia, J. Hydrol., 144, 59-84, 1993.

Hingston, F. J., Galbraith, J. H., and Dimmock, G. M.: Application of the process-based model BIOMASS to Eucalyptus globules subsp. Globules plantations on ex-farmland in south Western Australia: I. Water use by trees and assessing risk of losses due to drought., Forest Ecol. Manage., 106, 141-156, 1997.

Hoehn, E. and Scholtis, A.: Exchange between a river and groundwater, assessed with hydrochemical data, Hydrol. Earth Syst. Sci., 15, 983-988, doi:10.5194/hess-15-983-2011, 2011.

Holland, K. L., Doody, T. M., McEwan, K. L., Jolly, I. D., White, M., Berens, V., and Souter, N. J.: Response of the river murray floodplain to flooding and groundwater management: Field investigations, CSIRO, Adelaide, 65, 2009a.

Holland, K. L., Jolly, I. D., Overton, I. C., and Walker, G. R.: Analytical model of salinity risk from groundwater discharge in semi-arid, lowland floodplains, Hydrol. Process., 23, 3428-3439, $2009 b$.

HydroGeoLogic Inc: MODHMS: a comprehensive MODFLOWbased hydrologic modelling system, version 3.0, HydroGeoLogic Incorporated, Herndon, USA, 2006.

Jarwal, S. D., Walker, G. R., and Jolly, I. D.: General site description; Salt and Water Movement in the Chowilla Floodplain, CSIRO Division of Water Resources, 16-309, 1996.

Jolly, I. D., Walker, G. R., and Thorburn, P. J.: Salt accumulation in semi-arid floodplain soils with implications for forest health, J. Hydrol., 150, 589-614, doi:10.1016/0022-1694(93)90127-u, 1993.

Jolly, I. D., Walker, G. R., Hollingworth, I. D., Eldridge, S. R., Thorburn, P. J., McEwan, K. L., and Hatton, T. J.: The causes of decline in eucalypt communities and possible ameliorative approaches, in: Salt and Water Movement in the Chowilla Floodplain, edited by: Walker, G. R., Jolly, I. D., and Jarwal, S. D., CSIRO Division of Water Resources, Canberra, Australia, 1996.

Jolly, I. D., McEwan, K. L., and Holland, K. L.: A review of groundwater-surface water interactions in arid/semi-arid wet- lands and the consequences of salinity for wetland ecology, Ecohydrology, 1, 43-58, 2008.

Kollet, S. J. and Maxwell, R. M.: Integrated surface-groundwater flow modeling: A free-surface overland flow boundary condition in a parallel groundwater flow model, Adv. Water Resour., 29, 945-958, doi:10.1016/j.advwatres.2005.08.006, 2006.

Krause, S., Bronstert, A., and Zehe, E.: Groundwater-surface water interactions in a North German lowland floodplain - Implications for the river discharge dynamics and riparian water balance, J. Hydrol., 347, 404-417, doi:10.1016/j.jhydrol.2007.09.028, 2007.

Kristensen, K. J. and Jensen, S. E.: A model for estimating actual evapotranspiration from potential evapotranspiration, Nordic Hydrology, 6, 170-188, 1975.

Lamontagne, S., Leaney, F. W., and Herczeg, A. L.: Groundwatersurface water interactions in a large semi-arid floodplain: implications for salinity management, Hydrol. Process., 19, 30633080, 2005.

Leavesley, G. H., Restrepo, P. J., Markstrom, S. L., Dixon, M., and Stannard, L. G.: The modular modeling system (MMS): User's manual, USGS, Reston, Virginia, 1996.

Lenahan, M. J. and Bristow, K. L.: Understanding sub-surface solute distributions and salinization mechanisms in a tropical coastal floodplain groundwater system, J. Hydrol., 390, 131-142, doi:10.1016/j.jhydrol.2010.06.009, 2010.

Li, Q., Unger, A. J. A., Sudicky, E. A., Kassenaar, D., Wexler, E. J., and Shikaze, S.: Simulating the multi-seasonal response of a large-scale watershed with a 3D physically-based hydrologic model, J. Hydrol., 357, 317-336, 2008.

Liang, D., Falconer, R., and Lin, B.: Coupling surface and subsurface flow in a depth averaged flood wave model, J. Hydrol., 337, 147-158, 2007.

Loague, K. and VanderKwaak, J. E.: Physics-based hydrologic response simulation: platinum bridge, 1958 Edsel, or useful tool?, Hydrol. Process., 16, 1015-1032, 2004.

McLaren, R. G.: Grid Builder: A pre-processor for 2-D, triangular element, finite-element programs, Groundwater Simulations Group, University of Waterloo, Waterloo, Ontario, 2005.

MDBA: Report of the Independent Audit Group for Salinity 20082009, Murray-Darling Basin Authority (MDBA), Canberra, Australia, 2010.

Meire, D., De Doncker, L., Declercq, F., Buis, K., Troch, P., and Verhoeven, R.: Modelling river-floodplain interaction during flood propagation, Nat. Hazards, 55, 111-121, 2010.

Moench, A. F. and Barlow, P. M.: Aquifer response to stream-stage and recharge variations. I. Analytical step-response functions, J. Hydrol., 230, 192-210, 2000.

Nasonova, O. and Gusev, E.: Investigating the ability of a land surface model to reproduce river runoff with the accuracy of hydrological models, Water Resources, 35, 493-501, doi:10.1134/s0097807808050011, 2008

Overton, I. and Jolly, I.: Integrated studies of floodplain vegetation health, saline groundwater and flooding on the Chowilla floodplain, South Australia, Integrated Studies of Floodplain Vegetation Health, Saline Groundwater and Flooding on the Chowilla Floodplain South Australia, 2004.

Panday, S. and Huyakorn, P.: A fully coupled physically-based spatially-distributed model for evaluating surface/subsurface flow, Adv. Water Res., 27, 361-382, 2004. 
Peck, A. J. and Hatton, T. : Salinity and the discharge of salts from catchments in Australia, J. Hydrol., 272, 191-202, 2003.

Peck, A. J. and Hurle, D.H.: Chloride balance of some farmed and forested catchments in Southwestern Australia, Water Resour. Res., 9, 648-657, 1973.

Petheram, C., Bristow, K. L., and Nelson, P. N.: Understanding and managing groundwater and salinity in a tropical conjunctive water use irrigation district, Agr. Water Manage., 95, 1167-1179, 2008.

Pilgrim, D. H., Chapman, T. G., and Doran, D. G.: Problems of rainfall runoff modelling in arid and semi-arid regions, Hydrol. Sci. J., 33, 379-400, 1988.

Qu, Y. and Duffy, C. J.: A semidiscrete finite volume formulation for multiprocess watershed simulation, Water Resour. Res., 43, W08419, doi:10.1029/2006WR005752, 2007.

Rassam, D. W.: A conceptual framework for incorporating surfacegroundwater interactions into a river operation-planning model, Environ. Model. Softw., 26, 1554-1567, 2011.

Ross, M. A., Tara, P. D., Geurink, J. S., and Stewart, M. T.: FIPR hydrologic model users' manual and technical documentation, University of South Florida, Tampa, 1997.

Shlychkov, V.: Numerical modeling of river flows with account for vortex generation at the channel-floodplain boundary, Water Resources, 35, 522-529, doi:10.1134/s0097807808050035, 2008.

Sophocleous, M.: Review: Groundwater management practices, challenges, and innovations in the High Plains aquifer, USAlessons and recommended actions, Revue critique: Pratiques, défis et innovations dans le domaine des de la gestion des eaux souterraines de l'aquifère des Grandes Plaines (High Plains), aux Etats Unis d'Amérique - Leçons et recommandations, 18, 559$575,2010$.

Sophocleous, M. S. and Perkins, P.: Methodology and application of combined watershed and ground-water models in Kansas, J. Hydrol., 236, 185-201, 2000.

Sophocleous, M., Koussis, A., Martin, J. L., and Perkins, S. P.: Evaluation of simplified stream-aquifer depletion models for water rights administration, Ground Water, 33, 579-588, 1995.

Squillace, P. J.: Observed and simulated movement of bank-storage water, Ground Water, 34, 121-134, 1996.

Sun, D. and Zhan, H.: Pumping induced depletion from two streams, Adv. Water Reso., 30, 1016-1026, 2007.

Therrien, R.: Three-dimensional analysis of variablysaturated flow and solute transport in discretely-fractured porous media, Ph.D., University of Waterloo, Waterloo, 1992.
Therrien, R. and Sudicky, E. A.: Three-dimensional analysis of variably-saturated flow and solute transport in discretelyfractured porous media, J. Contaminant Hydrol., 23, 1-44, 1996.

Therrien, R., McLaren, R. G., Sudicky, E. A., and Panday, S. M.: HydroGeoSphere: A Three-Dimensional Numerical Model Describing Fully-Integrated Subsurface and Surface Flow and Solute Transport, Groundwater Simulations Group, University of Waterloo, Waterloo, Canada, 2005.

Therrien, R., McLaren, R. G., Sudicky, E. A., and Panday, S. M.: HydroGeoSphere; A Three-dimensional Numerical Model Describing Fully-integrated Subsurface and Surface Flow and Solute Transport: User Manual, Groundwater Simulations Group, University of Waterloo, Waterloo, Ontario, Canada, 2010b.

VanderKwaak, J. and Loague, K.: Hydrologic-response simulations for the R-5 catchment with a comprehensive physics-based model, Water Resour. Res., 37, 999-1013, 2001.

VanderKwaak, J. E.: Numerical simulation of flow and chemical transport in integrated surface-subsurface hydrologic systems, $\mathrm{PhD}$, University of Waterloo, Waterloo, Canada, 1999.

van Genuchten, M. T.: A closed-form equation for predicting the hydraulic conductivity of unsaturated soils, Sci. Soc. Am. J., 44, 892-898, 1980.

Verstrepen, L.: Evaluating rainwater harvesting on watershed level in the semi-arid zone of Chile, M.Sc., Bioscience Engineering, Universiteit Gent, Gent, 113 pp., 2011.

Viezzoli, A., Auken, E., and Munday, T.: Spatially constrained inversion for quasi 3D modelling of airborne electromagnetic data - an application for environmental assessment in the Lower Murray Region of South Australia, Exploration Geophysics, 40, 173 183, doi:10.1071/EG08027, 2009.

WaterConnect: River murray water data, available at: https://www. waterconnect.sa.gov.au, last access: 5 April 2013.

Wheater, H. S., Mathias, S. A., and Li, X.: Groundwater Modelling in Arid and Semi-Arid Areas, Cambridge University Press, 2010.

White, M. G., Berens, V., and Souter, N. J.: Bookpurnong Living Murray Pilot Project: Artificial inundation of Eucalyptus camaldulensis on a floodplain to improve vegetation condition, Science, Monitoring and Information Division, Department of Water, Land and Biodiversity Conservation, 2009.

Winter, T. C.: Relation of streams, lakes, and wetlands to groundwater flow systems, Hydrogeoly J., 7, 28-45, 1999. 